\title{
THE USE OF SPANISH HISTORICAL ARCHIVES TO RECONSTRUCT CLIMATE VARIABILITY
}

\author{
by Ricardo García Herrera, Rolando R. García, M. Rosario Prieto, \\ Emiliano Hernández, Luis Gimeno, and HenRy F. Díaz
}

\begin{abstract}
Spanish historical archives are a potentially important source of climate-related information over a wide range of timescales and geographical locations.
\end{abstract}

$\mathrm{T}$ he use of documentary sources is a well-established technique for reconstructing climate during the past few centuries, when no instrumental or similar sources of data are available. Such sources have been used to study climate phenomena such as El Niño-Southern Oscillation (ENSO; Quinn et al. 1987; Quinn and Neal 1992; Ortlieb 2000) and the North Atlantic Oscillation (NAO; Jones et al. 1997; Luterbacher et al. 1999). They have also been used to describe regional climate variability, especially in Europe and Asia. In recent years, substantial efforts have been made to obtain climatic information from Spanish colonial archives covering the period 1500-

affiliations: García Herrera, and HernándeZ-Universidad Complutense, Madrid, Spain; GARCíA—National Center for Atmospheric Research, Boulder, Colorado; PRIETO-CRICYT, Mendoza, Argentina; Gimeno-Universidad de Vigo, Orense, Spain; DíAZ-Climate Diagnostics Center, NOAA, Boulder, Colorado CORRESPONDING AUTHOR: Rolando R. García, National Center for Atmospheric Research, 1850 Table Mesa Drive, Boulder, CO 80303

E-mail: rgarcia@ucar.edu

DOI: 10.II75/BAMS-84-8-1025

In final form 2 May 2003

(C2003 American Meteorological Society
1900. Spaniards arrived in the Antilles at the end of the fifteenth century and, after $50 \mathrm{yr}$ of constant advance, they had established themselves throughout most of the southern part of the New World. Interestingly, southern South America, the most inaccessible region, provides some of the earliest historical records, such as Ferdinand Magellan's navigation in 1520 of the strait that bears his name. As colonization advanced, new lands were incorporated and new cities were founded. Valuable historical information started to emerge from cities such as Santa Marta (1527) and Caragena de Indias (1553), in Columbia; Lima, Perú (1532); Santiago de Chile (1541); Asunción del Paraguay (1541); and Mendoza, Salta, Jujuy, Tucumán, and Buenos Aires, all in Argentina (1561-80) (Morales Padrón 1973). Figure 1 shows the location and foundation dates of the most important Spanish colonial cities.

The nature and origin of documents that can be used to reconstruct climate are extremely diverse. Some, such as ship logbooks, city council records, and chronicles, originated from reporting requirements imposed by the Spanish Crown; others, like travelers's descriptions and diaries, resulted from the initiative of private citizens. The reports of scientific expeditions are also a valuable source of climatic and environmental information, as are the large number of 


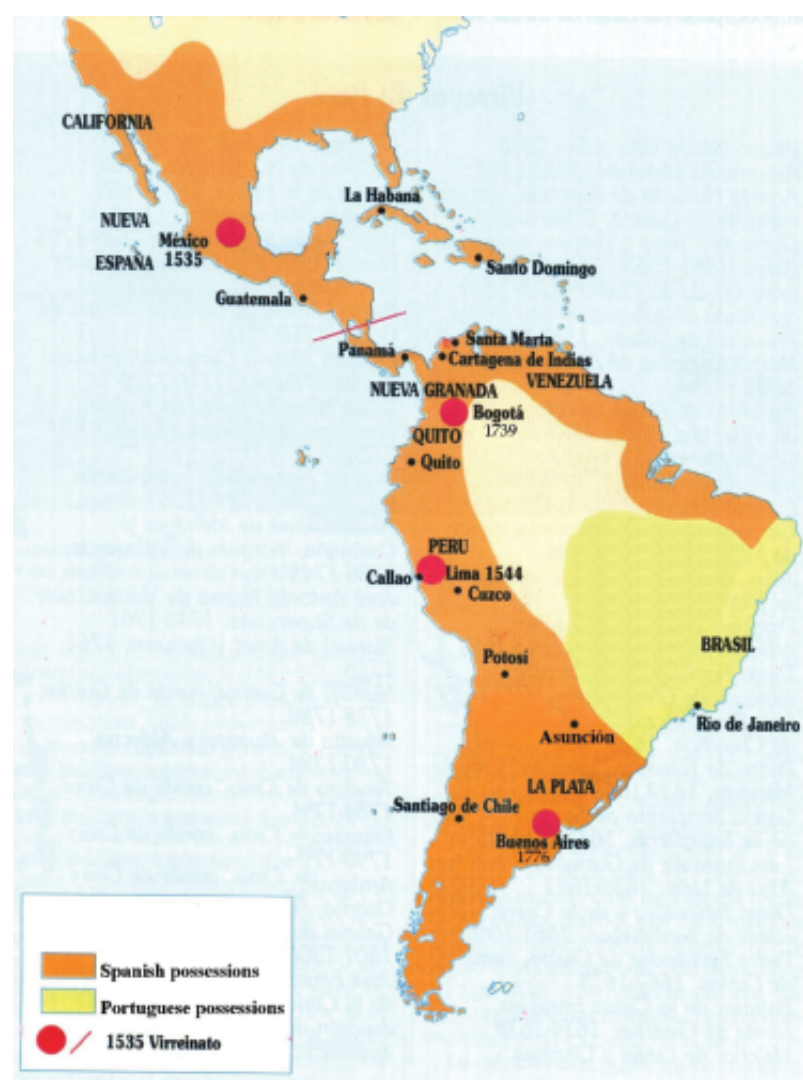

FIG. I. Map of the American continent showing the location and date of foundation of the most important Spanish colonial cities, and the four principal subdivisions of Spain's colonial empire (viceroyalties of Nueva España, Nueva Granada, Peru, and La Plata).

reports written by members of religious orders (see, e.g., Udías 1996). However, not all of these documents are equally useful as sources of climatic information. Thus, the reports from expeditions or travelers can be very detailed, but they usually refer to very short periods of time, so they are not particularly well suited for studying climate variability. On the other hand, local chronicles, although usually not very detailed, span much longer periods and can yield an adequate perspective on variability over interannual, decadal, and even longer scales.

These documents are presently held in different archives, either in Spain or Spanish America. In Spain, the most significant are the Archivo General de Indias (General Archive of the Indies; AGI), in Seville, the Archivo del Museo Naval (Archive of the Naval Museum; AMN), in Madrid, the Archivo Central de la Marina (General Archive of the Navy; AGM), in Viso del Marqués, the Archivo General de Simancas (General Archive of Simancas; AGS), in Simancas and the Archivo Histórico Nacional (National Historic Archive; AHN), in Madrid. The AGI, in particular, contains a vast amount of information covering all aspects of Spain's relations with its American colonies, while the AMN and AGM hold extensive collections of logbooks.

The contents of the archives are usually divided into "sections" or "series," each one covering a different area of administrative, social, political, or military affairs. Within each such division are found a highly variable number of legajos, or manuscript bundles, consisting of some 1500-2000 manuscript pages on related topics. The organization of the archives varies greatly, depending on their origin and purposes. For example, the organization of the AGI reflects the administrative structure of the Spanish colonies more than any other criterion (see, García et al. 2001, for a more detailed description on the AGI). On the other hand, the AMN is organized according to the origin of its collections, and comprises four main divisions: Depósito Hidrográfico (Hydrographic Depository), Real Compañía de Guardamarinas (Royal Company of Navy Cadets), Fondos de Adquisiciones y Donaciones (Acquisitions and Donations), and Museo Naval (Naval Museum).

Other significant documents have survived in Spanish America itself; these are presently kept in different cities, in provincial or national archives. Depending on the administrative status of the city, the information preserved may refer to the region in the immediate vicinity of the city, or to much wider areas under the city's jurisdiction. The most important administrative and political unit in Spanish America was the viceroyalty. Starting in 1544 two viceroyalties were established: one in Mexico (Nueva España), which included all the territories north of present day Panama, plus Venezuela and the Caribbean Islands, and a second one in Lima (Peru), governing the rest of the Spanish possessions. During the eighteenth century two new viceroyalties were carved out from Lima: Nueva Granada (1739), with the capital in Santa Fe de Bogotá and jurisdiction over today's Venezuela, Colombia, Panama, and Ecuador; and Río de la Plata (1776), whose capital was Buenos Aires and governed Bolivia, Paraguay, Uruguay, Argentina, and part of Chile. The highly centralized and bureaucratic character of the Spanish empire led to the production of a huge volume of documents, which provide a thorough coverage of the colonial territories. This administrative hierarchy has a counterpart in present-day archives. Thus, the National Archives at Mexico City and Lima provide the greatest wealth of information, usually extending beyond the present borders of these countries. However, additional information from the cabildos (local city 
councils) can be found in a number of local and provincial archives. The organization and structure of the cabildo archives varies, depending on the country and the city.

The goal of this paper is to describe and discuss some strategies and techniques used to obtain climaterelevant information from these documentary records. The next three sections illustrate, by means of specific examples, three types of situations that are often encountered when trying to extract usual data from historical archives: the treatment of noninstrumental meteorological observations, the interpretation of documents that provide explicit information on climatic events or impacts, and the development of climate proxies. The final section summarizes the principal methodological issues and provides some guidelines, derived from the authors' own experience, that may be useful for other researchers interested in obtaining climatological information from historical sources.

NONINSTRUMENTAL OBSERVATIONS. Climatologists are most interested in long series of observations that can be used to define climate normals and to study climatic variability. Spanish colonial archives contain a certain amount of such data; perhaps the most obvious example being the logbooks of merchant and military ships. A royal order issued in 1575 required masters and pilots of Spanish ships in the Carrera de Indias (the route from the mainland to the American colonies) to keep a record of each trans-Atlantic journey, including a detailed description of the voyage and of any geographical discoveries, winds, current, and hurricanes. The completed logbooks had then to be delivered to the Professor of Cosmology in the Casa de Contratación (AGI, Indiferente General, 1956, L1, f 266r-266v). ${ }^{1}$ As the Spanish Administration evolved, the logbooks were kept by different authorities; at the end of the colonial period, the logs were archived by either the Navy or the Post Office authorities.

By the beginning of the eighteenth century, with many ships traveling between the metropolis and the colonies, the logbooks include detailed records of atmospheric and oceanic conditions. Toward the end of the eighteenth century, as barometers and thermometers came into common use, the earlier descrip- tions of weather events began to be accompanied by instrumental records. Nonetheless, even the earlier logbooks, from the sixteenth and seventeenth century, contain much reliable information because their crews included highly skilled officers, well aware that their lives and careers depended on the ability to observe the weather (Wheeler 1988). Figure 2 shows a reproduction of a page from the logbook of the frigate San Andrés, on her way from Manila, Philippines, to Acapulco, Mexico in 1796 (AMN, Ms 201). ${ }^{2}$ It provides hourly data on the heading of the ship (rumbo), wind direction (viento), strength (fuerza), state of the atmosphere (caris, or cariz in modern Spanish), rigging (aparejo), and direction and distance run by the ship. Midday position and a brief description of the most relevant daily events are entered at the bottom of the page.

Logbooks are a unique source of historical data because their purpose is to describe, as precisely as possible, the state of certain meteorological variables (wind strength, wind direction, precipitation, etc). In principle the data they contain resemble those of the instrumental period, except that descriptive terms are used instead of numerical values. Fortunately, thousands of these logbooks-mainly those kept by the fleets that sailed the Atlantic-have survived and are available in different archives. They are structured along the lines of the example shown in Fig. 2, and provide high-resolution (sometimes hourly) observations, with a high level of correlation among logbooks from different ships and officers.

Interpretation of meteorological entries from ships' logs is one of the most immediate and straightforward applications of historical data to climate studies. However, it is not at all a trivial exercise, especially when large amounts of data are involved, because extensive processing is necessary to convert the handwritten logbook entries into a computer database suitable for quantitative study. Systematic transcription of logbook data from Spanish archives is currently being carried out under the Climatological Database for the World's Oceans 1750-1850 (CLIWOC) project. This project is funded by the European Union, and its chief aim is to obtain some one million logbook observations from Spanish, British, Dutch, and French archives for the period 1750-1850 (see www.ucm.es/info/cliwoc for a detailed descrip-

\footnotetext{
${ }^{1}$ References to manuscript sources in the Archivo General de Indias are denoted by the initials AGI, followed by the name of the section of the archive where the manuscript is located, and a series of numbers identifying the legajo, or bundle, to which the manuscript belongs.

${ }^{2}$ Documents in the collection of the Museo Naval of Madrid are catalogued simply by the legajo number.
} 


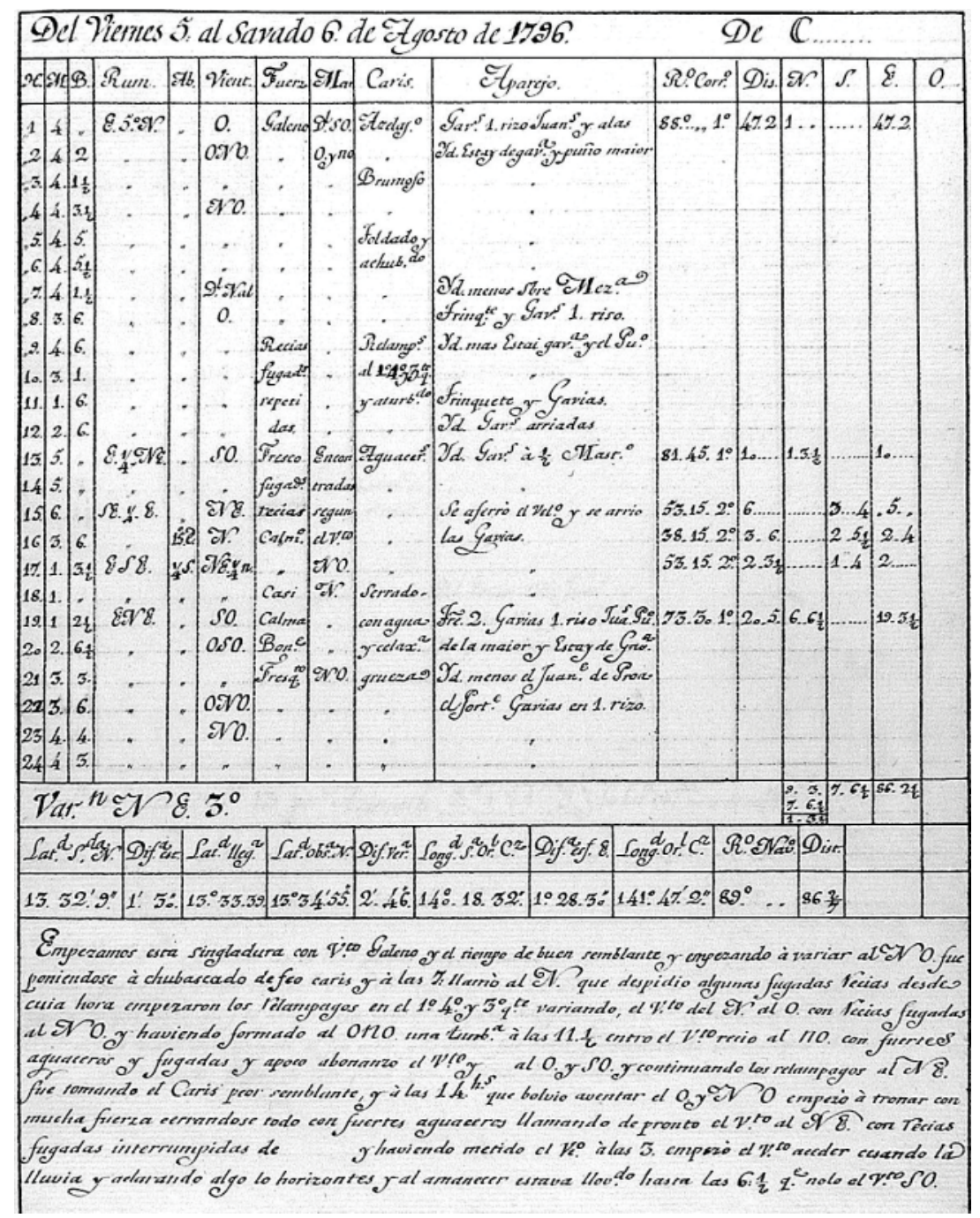

Fig. 2. Reproduction of a page from the logbook of the frigate San Andrés on her way from Manila to Acapulco (AMN, Ms 20I; reproduced with permission of the AMN, Madrid, Spain). The title at the top of the page shows the period of record (from Friday, 5 to Saturday 6 Aug 1796). The main section contains entries for the time of day, heading, wind direction and strength, state of the weather, rigging, etc (note that the 24-h day begins at local noon, standard practice on Spanish ships in the eighteenth century). The summary at the foot of the page reads approximately as follows: "We began this leg under a Galeno [a category 4-5 wind on the Beaufort scale] and fair weather. [The wind then] began turning to the NW, the weather worsening and becoming showery, and at 7 [p.m.] it turned to the $\mathbf{N}$ with some strong gusts, at which time lightning started in the Ist, 4th, and 3rd, quadrants. The wind [then turned] from $\mathbf{N}$ to $W$, with strong gusts from the NW. A storm having formed WNW, at I I:30 [p.m.] the wind blew strongly from the NW with heavy rain and gusts. Shortly thereafter, the wind slackened, blowing from the W and SW, with lightning continuing on the NE. The weather [later] worsened and, at 14 hs. [2 a.m.] the wind blew again from the W and NW, with loud thunder, lowering clouds and heavy rain. The wind [then] turned suddenly to the NE with strong gusts until 3 [a.m.], when it started to weaken, the rain ceased, and the horizon became clearer. At dawn, it rained until 6:30 [a.m.], when the wind turned to the SW." tion). In what follows we describe the processing required to obtain wind data comparable to that available from modern records.

As can be seen in Fig. 2, wind observations refer to both speed and direction. The interpretation of wind direction records is straightforward, because standard compass directions were used. Wind speed data, on the other hand, require much more careful work. Of course, no anemometers were available on board these sailing ships, but, as previously mentioned, the officers were highly skilled in estimating wind from the state of sea, sails, and clouds. These estimates were recorded using descriptive terms rather than expressed numerically. In the case of Spanish logbooks, a large variety of terms were used to classify the intensity of the wind; recent work by García Herrera et al. (1999) has identified as many as 36 different terms used to describe wind intensity.

Thus, the first task in this type of study is to construct a dictionary to translate the historical terms into modern equivalents; the use of contemporary and historical marine dictionaries is indispensable for this purpose. However, this is not enough because nautical terminology usually evolves significantly over the time span of a century, so the dictionary itself needs to evolve to cope with these changes. Content analysis (Baron 1982) can be a useful tool to overcome this kind of problem. Once a dictionary has been completed, the original readings can be converted into their modern equivalents 
and introduced into the database. In spite of these difficulties, intercomparison exercises (e.g., Wheeler 1988) demonstrate the coherence of the information from logbooks which can, therefore, be considered highly reliable.

Similar procedures must be repeated for other variables of interest that are often found in logbooks, such as precipitation, current weather, or the state of the sea. Only then can the data be considered to be available for use by the scientific community. Clearly, successful extraction of weather data from ships' logbooks requires a major, coordinated effort using a combination of expertise from fields such as climatology, history, and linguistics, among others. Figure 3 shows the average wind directions for the postal route from La Coruña, Spain, to Havana, Cuba, back to La Coruña, from a sample of 166 trips for the period 1764-69. A $5^{\circ} \times 5^{\circ}$ grid has

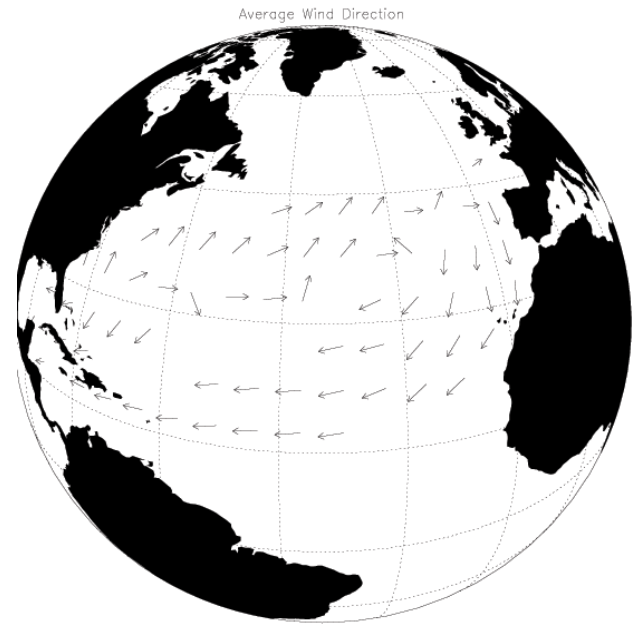

FIG. 3. Reconstruction of the average wind directions using logbook data for the postal route from La Coruña to Havana to La Coruña, from a sample of 166 trips in the period 1764-69. been used to represent wind

direction. It is expected that, when all the logbooks are finally examined, the database will provide evidence on the variability of the Azores subtropical high.

\section{DESCRIPTIONS OF WEATHER EVENTS.}

Explicit meteorological data, such as that described above, will be immediately familiar and useful to climatologists. However, the historical archives contain other types of information whose application is not as immediate as that of the logbook data. This is usually in the form of reports about specific weather events or impacts in a certain city or region (e.g., crop reductions, destruction of buildings). The use of such sources is complicated by the fact that few documents deal specifically with weather; instead, meteorological information has to be gleaned from documents of a very diverse nature. An outstanding example are the Actas Capitulares, or city council records.

The Actas have been especially fruitful for climatic studies. They summarize the meetings of the cabildos. Although the cabildos were a colonial institution, they often remained in existence well into the republican period in many of the former Spanish colonies.
The cabildos met weekly, usually on Saturdays, and every session was carefully documented by the escribano (recorder) who had the responsibility of producing a faithful account of the meeting and caring for the books. The members of the cabildo were in charge of many aspects of the affairs of the city: its military and defensive organization, water supply, economy, etc. In addition, they were invested with the power of issuing local laws. Their role was especially important when the city faced some crisis, such as a flood, drought, or earthquake, that impacted the lives or livelihood of the citizens. The Actas are among the most reliable sources of climatic information partly because accounts of weather events or descriptions of the climate are not their main purpose. Thus, the chances of intentional distortions of the events described are less than with other documents. Additionally, when collections are well preserved, the Actas constitute a continuous source with daily or weekly resolution, spanning long periods.

Unfortunately, not all the Actas have survived. Wars, political instability, and poor archival conditions, especially during the unstable nineteenth century, have resulted in the loss of some collections. However, in many cases they have been adequately preserved and have even been published. Some examples include the complete collections for the Argentine cities of Santiago del Estero (covering the period 1554-1810; Academia Nacional de la Historia 1941-1951), and Corrientes (Academia Nacional de la Historia 1941-1946). From La Paz (Bolivia), only those for the period 1548-52 have survived. On the other hand, Potosí (Bolivia) has preserved a collection of exceptional quality that has been studied recently by Gioda and Prieto (1999). The extraction of information from the Actas requires extensive knowledge of the contents and organization of the archive in question. Extreme events, such as floods, droughts, or hurricanes, are especially well recorded in these documents, as is shown in the following example: 
Actas Capitulares de la provincia de Mendoza (Argentina) 11 de abril de 1662 (ACM, Vol. 3, p. 220) ${ }^{3}$

“. . por cuanto martes a medianoche 11 del corriente fue Dios nuestro Señor servido de enviar una avenida conque asoló $y$ arruinó la mayor parte de la ciudad y entre ellas fueron las casas del Cabildo y cárcel que no se pueden habitar ni hacer juicio en ellas por estar caidas ..." [. . . whereby at midnight on Tuesday the 11th of the current month, it was the will of our Lord to send a flood that leveled and ruined the greater part of the city, including the house of the cabildo and the jail, so that they have become uninhabitable and unsuitable for holding trials since they have collapsed ....].

Drought in northern Argentina. An example of the use of the Actas and similar historical sources to detect climate fluctuations can be found in Prieto et al. (2000). This paper examines climate variability in seven locations in northern Argentina during the sixteenth-nineteenth centuries and illustrates the need for integrating information from different archives and types of document. The study employed Actas Capitulares from the area (found in local archives and in the AGI); local reports on plagues from local archives; miscellaneous administrative documents from the AGI; Relaciones Semestrales (semestral reports on precipitation and crops produced under an order of the Crown during the eighteenth century, which are archived locally and in the AGI); diaries from private citizens, trav-

\footnotetext{
${ }^{3}$ The Actas Capitulares of the province of Mendoza are organized according to bound (manuscript) volumes within the provincial archive; however, they have not been published.
}
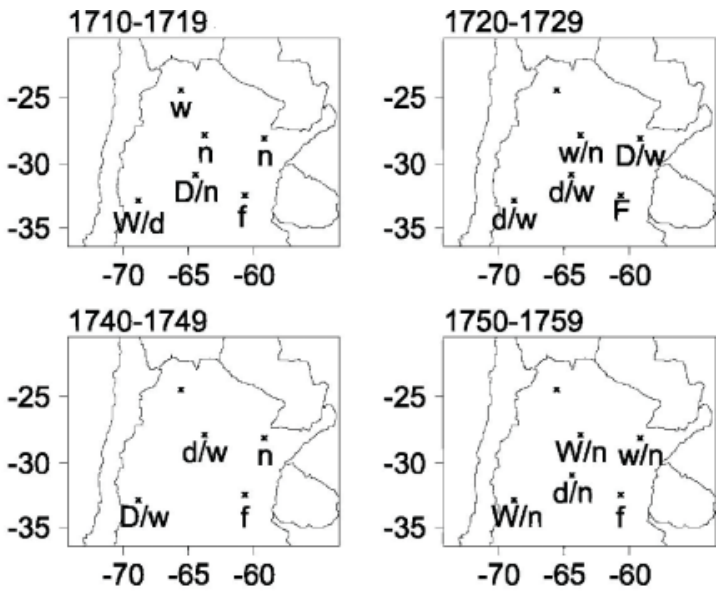

$1770-1779$
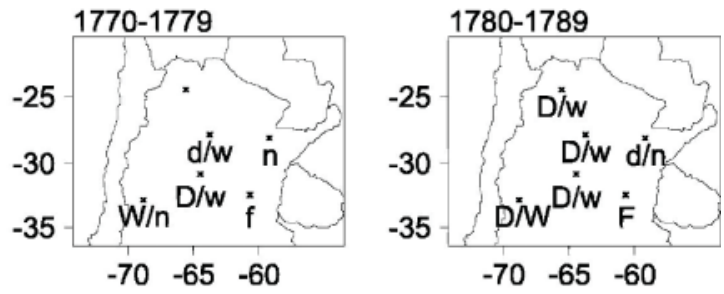

1800-1809
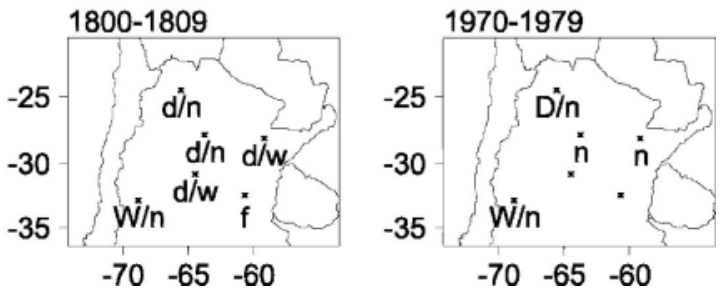

Fıg. 4. Decadal variability of climatic conditions in northern Argentina during the eighteenth century. The letters on the maps denote indices for precipitation (W: very wet, w: wet, n: normal, d: dry, D: very dry) and flooding (f: some floods, F: massive floods). For every decade, the two most frequent precipitation conditions have been indicated. The first panel shows the locations used to characterize the climate of the region (I: Northwestern, 2: Arid Chaco, 3: Humid Chaco, 4: Cordoba humid plains, 5: Mendoza arid and semiarid plains, and 6: Rio de la Plata basin). Conditions for the period 1970-79 have been included in the last panel for comparison. Reproduced from Prieto et al. (2000).

elers, and members of religious orders; and records from missions (found in local archives, in the AGI, or published separately).

From these sources, continuous series of annual anomalies of precipitation, runoff, and floods for the selected area for the period 1580-1806 were developed (see Table 1 of Prieto et al. 2000). Due to the heterogeneous character of the primary sources, careful interpretation and cross-checking were required to obtain a homogeneous record before content analysis could be applied to convert the original information into a qualitative, homogeneous scale. In this way, anomalies were classified within five categories for precipitation (very wet, wet, normal, dry, and very dry) and within two categories for the occurrence of 
floods (some floods and massive floods). Although this procedure is time consuming and requires a high level of expertise in the interpretation of the terminology employed in the original documents, the use of primary sources and overlapping references to the same phenomenon makes for a high degree of reliability. Figure 4 shows the decadal variability of climatic conditions in northern and central Argentina during the eighteenth century. For each location, the prevailing conditions for every decade have been indicated. It can be seen that the period $1780-1800$ is one of frequent, severe droughts and high precipitation variability compared to earlier decades of the eighteenth century and to modern values (1970-79, shown in the lower right-hand panel). This demonstrates how the combined use of the documentary sources provides a century-scale perspective on the regional climate of the area that cannot be obtained from other sources.

Atlantic hurricanes. Another example of the use of weather descriptions in climate studies is the reconstruction of Atlantic hurricanes (García Herrera et al. 2002). This paper describes the results of a nonexhaustive search in different Spanish archives (see the introduction for a list). It shows that the archives contain abundant references to weather disasters on the Caribbean coasts. They usually refer to hurricanes or intense storms and describe damages in lives and property. For Cuba and Puerto Rico, in particular, there are records covering more than $400 \mathrm{yr}$ (approximately 1500-1898). Of special interest are the Reports of the General Navy Command of the Antilles, the Gazetas, and other periodic publications, such as the Partes de tranquilidad (included in the Papeles de Cuba section of the AGI), the monthly papers produced by the authorities, or the reports from the meteorological services established in the area during the nineteenth century.

The occurrence of hurricanes in the open ocean is better described in ships' logs, especially those from the annual silver fleets that traveled between the Spanish main and the metropolis. In turn, the logbooks can be complemented by other types of reports, for instance, claims for compensation for losses of merchandise in shipwrecks. As shown by Garcia Herrera et al., 127 hurricanes or severe storms were identified using the information extracted from these sources. Figure 5 provides a summary of the results. It can be seen that most of the information refers to the second half of the eighteenth century. It is still unclear whether this is the result of a higher frequency of hurricanes or greater availability of sources. Regarding spatial coverage, Cuba, Puerto Rico, Florida, and Louisiana are the areas with the most available information.

Figure 5 also illustrates one of the main problems involved in this type of study: the need for a careful and systematic search of the archives. Fourteen sec-

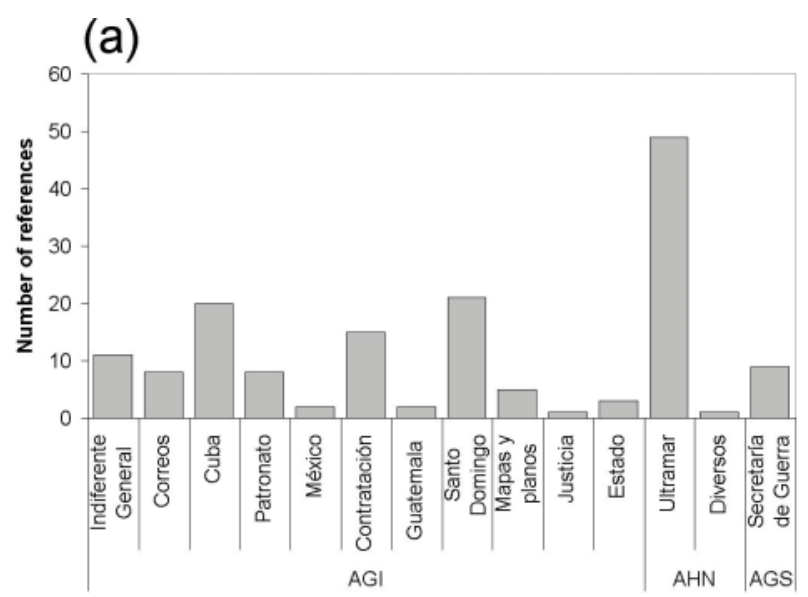

(b)

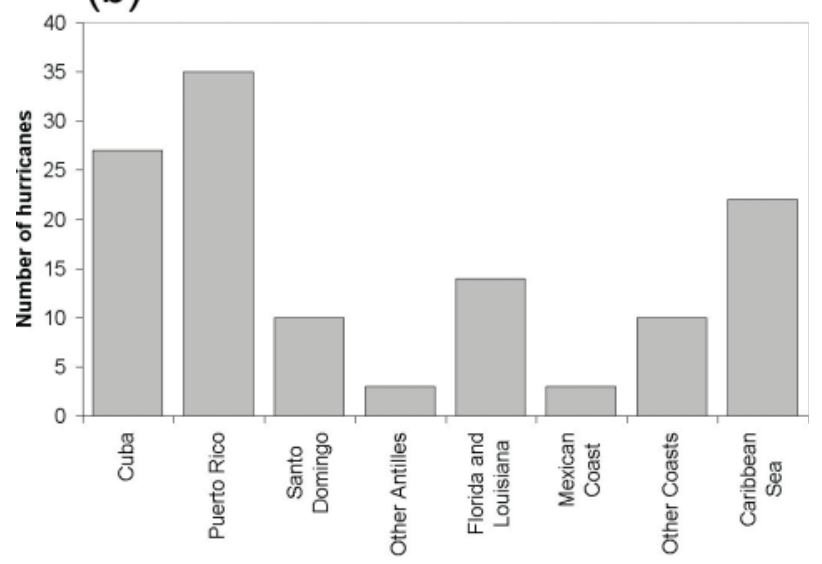

(c)

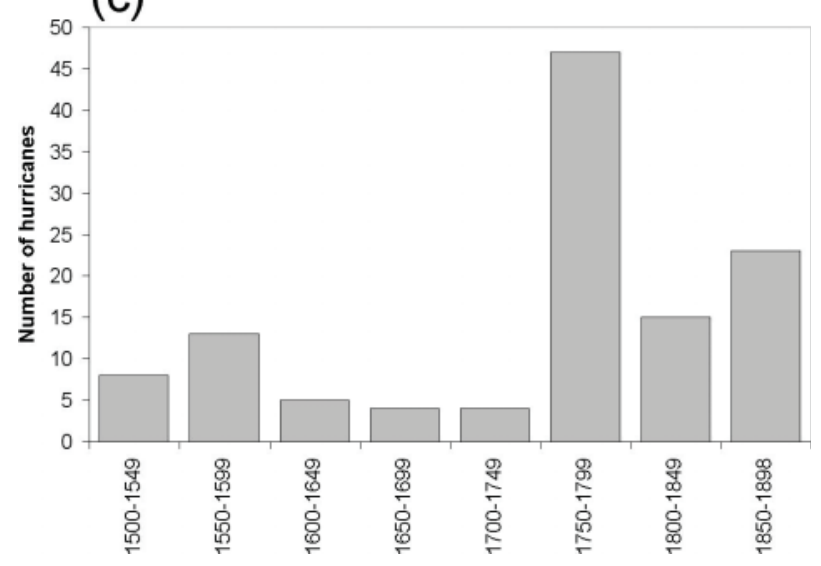

FIG. 5. Distribution of the hurricanes identified from historical documents according to (a) archive and section, (b) geographical area, and (c) in 50-yr intervals between 1500 and 1898 . 
tions in three different archives were identified as containing references to hurricanes, in many cases with unexpected results. For instance, it was not expected a priori that sections of a rather bureaucratic nature, such as Contratación (Contracts) or Patronato (Royal Patronage), could provide a high percentage of the references to hurricanes. Thus, although the search process can be very time consuming, it can yield unique information. In this admittedly preliminary exercise, about $30 \%$ of the hurricanes were unreported by previous authors. In fact, most of the previous historical series of Atlantic hurricanes have been constructed from sources in the Americas, but the peninsular archives had hitherto remained unexplored for these purposes. This highlights the value of these sources, because they can provide independent evidence to refine hurricane chronologies, tracks, and effects.

Reevaluation of historical chronologies of ENSO. A final example illustrates the pitfalls associated with the interpretation of documents that describe meteorologically significant events. Because the sources, authors, and purposes of these documents can be varied, different aspects need to be considered when assessing their reliability. For instance, it is important to ascertain whether the sources are primary (original documents, with firsthand information) or secondary (studies or inferences made from other documents, or relations from people who were not actual witnesses to the facts). If the sources are not original, different interpretations can lead to disparate results; the recent revision by Ortlieb (2000) of previous chronologies of ENSO by Quinn and Neal (1992) and Quinn et al. (1987) is a case in point.

The papers of Quinn and coauthors are one of the most widely referenced chronologies of ENSO, but they have been developed mostly from secondary sources, such as reports from floods, droughts, loss of crops, plagues, and migration of fisheries from different locations in South America (mainly Peru, Bolivia, and Brazil). In addition, somewhat esoteric indicators, such as flow volume for the Nile River in Egypt, have been included in the analysis on the basis of possible teleconnection effects. Ortlieb (2000) critically reviews these results, evaluating the reliability and significance of the sources used to identify each ENSO event. As a result of this new analysis Ortlieb concludes that, of the 86 ENSO events identified by Quinn et al., 42 are doubtful. In addition, Ortlieb identifies seven events not previously associated with ENSO by Quinn and coauthors.

\section{INTERPRETATION OF CLIMATE PROXIES.}

Documentary sources have been used in the past as climate proxies, particularly for the study of major teleconnection patterns. The term "proxy" refers to variables that are related to climate phenomena, but are not direct observations or descriptions of weather events. Historical sources can provide valuable proxies but, as already noted, historical data are often subject to problems of interpretation. Most often this occurs because of shortcomings of the data itself; for example, is the apparent variability in the frequency of Atlantic hurricanes real or is it affected by nonuniform sampling? Are the proxies chosen to identify ENSO events unequivocally related to these events? On the other hand, it is also possible to encounter a proxy series wherein the data themselves are unambiguous, but their geophysical significance is unclear. The use of modern analogs can be a useful tool for interpreting the meaning of the series in such cases, as done in the recent study by García et al. (2001).

This study focused on the climatic information that could be derived from the voyages of the Manila galleons. These ships carried out a regular commercial route between the Philippine Islands, and Acapulco, Mexico, throughout the period 1565-1815. Because they operated regularly and the Manila-bound ships sailed in the tropical Pacific, near $12^{\circ} \mathrm{N}$, documents describing the voyages have obvious potential as sources of climatic information. Unfortunately, and in contrast to the Atlantic voyages described in the section titled "Descriptions of Weather Events," very few logbooks from the Manila trade have survived. These were first and foremost commercial voyages, financed by private parties, and the route was so remote from the metropolis that many Crown regulations were disregarded. In any case, less than $10 \%$ of the Manila-Acapulco voyages are documented in logbooks, so that the rich, high-resolution observations common in the records of the Atlantic fleets are not available.

Instead, it was possible to obtain the dates of departure and arrival at port from documents held mostly by the AGI. Thus, a series of duration of the voyages based on objective data (the dates recorded in the documents), and to all appearances free of subjective influences, was generated. A number of studies were conducted to determine the potential influence of changes in the starting date of the voyages, ship design, type of cargo, and route (see García et al. 2001 for more details). All of them led to the same conclusion: climate variability was the likely cause of 
the behavior detected in the series. The problem then became one of inferring the significance of the series, which showed very large secular trends during the mid-seventeenth century, as can be seen in Fig. 6 .

The duration of a sailing voyage between Acapulco and the Philippines is an integral measure of the strength and direction of the winds along the trajectory followed by the ships; however, it lacks specific information on any details of geophysical interest. For example, did secular trends in voyage duration reflect uniform changes in the trade wind circulation, or was local variability more important and, if so, where? The use of modern data provided the key to a plausible solution of this problem. García et al. (2001) constructed "virtual voyages," wherein the trajectories of idealized ships sailing from Acapulco to the Philippines were computed using winds for the period 1948-99 obtained from the National Centers for Environmental Prediction-National Center for Atmospheric Research (NCEP-NCAR) reanalysis (Kalnay et al. 1996; Kistler et al. 2001). The results showed that the occurrence of the slowest or fastest virtual voyages was closely related to the position of the southwest monsoon trough during the month of June, when the ships approached the Philippine archipelago. In short, displacement of the monsoon trough north and eastward of its ensemble-mean position resulted in slow virtual voyages, and vice versa. Figure 7 illustrates this result.

Thus the analysis of the virtual voyages led to the hypothesis that the secular trends observed in the historical series of voyage duration were likewise attributable to changes in the southwest monsoon circula-

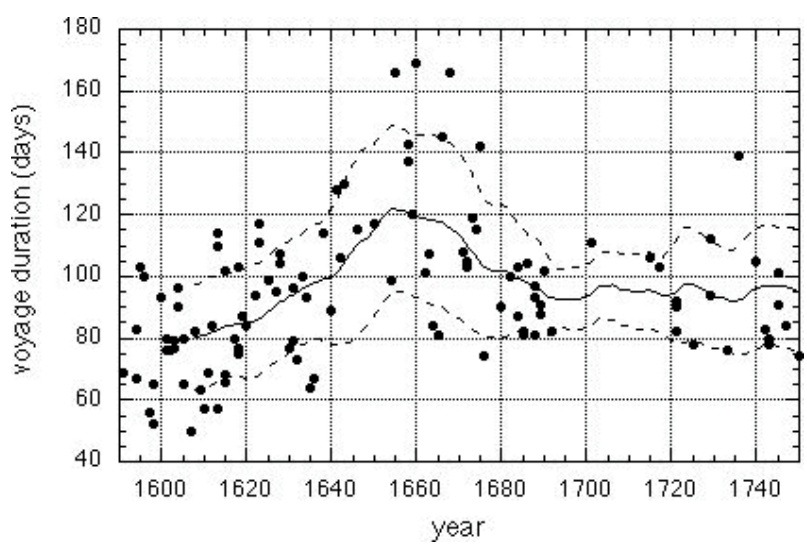

FIG. 6. The time series of voyage duration from Acapulco, Mexico, to the Strait of San Bernardino, in the Philippines, I591-1750. The 30-yr running mean is denoted by the solid line; the dashed lines indicate the mean \pm I std dev. tion. The plausibility of this hypothesis was reinforced by comparison with recent studies (e.g., Fu and Fletcher 1988) that demonstrate that large, long-term changes in the strength and position of the southwest monsoon trough have occurred throughout the twentieth century. Taken together, these results provided a strong indication that the atmospheric circulation of the western Pacific underwent large, multidecadal fluctuations during the seventeenth century.

Fast Voyages

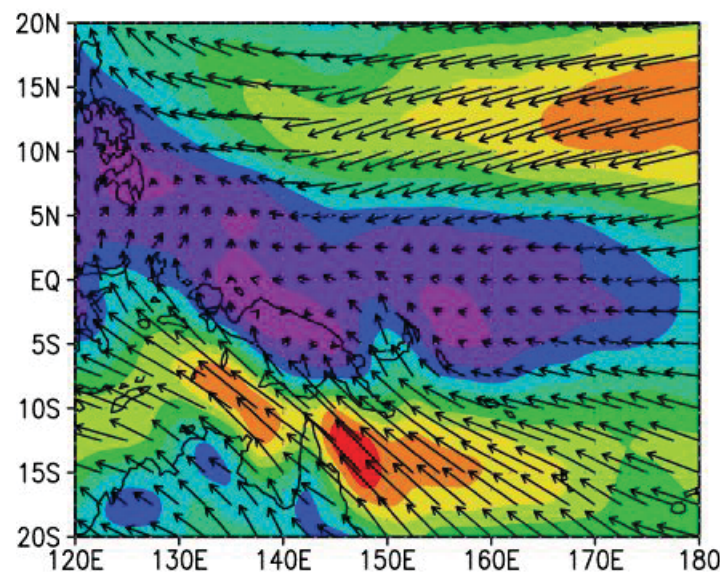

10

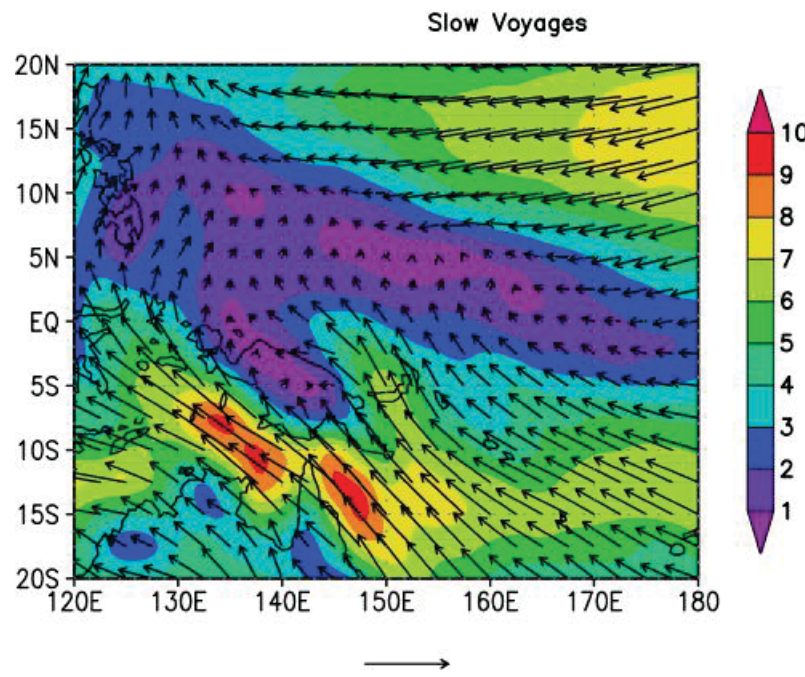

Fig. 7. Mean Jun wind field $\left(\mathrm{m} \mathrm{s}^{-1}\right)$ for ensembles of $9 \mathrm{yr}$ with the fastest and slowest virtual voyages. Arrows indicate the vector wind, and colors the wind magnitude $\left(\mathrm{m} \mathrm{s}^{-1}\right)$. The north and eastward shift of the southwest monsoon between the fastest and slowest voyage years is evident. The NCEP-NCAR reanalysis data was provided by the National Oceanic and Atmospheric Administration-Cooperative Institute for Research in Environmental Sciences (NOAA-CIRES) Climate Diagnostics Center. 
CONCLUDING REMARKS. The extraction of climatic information from documentary sources can be a very time-consuming effort. In many cases the documents have not been scanned or catalogued electronically, so that the originals have to be consulted. Even when documents are available in digital form and are correctly catalogued, little information can be found under meteorological or climatological headings. Thus, a search of many different sections of the archives and diverse documents is almost always required. Finally, the miscellaneous nature of the archives often requires a high level of expertise in areas such as history and paleography.

In the study of the Manila galleons just discussed, thousands of documents from eight different sections of the AGI sections were consulted. For every voyage, the following data had to be obtained to determine its duration: the name of the ship, date of departure from the Manila, date of arrival at and departure from Acapulco, and date of arrival at Manila. Similarly, thousands of pages of Actas Capitulares were read to obtain the raw information needed to establish the precipitation anomalies documented by Prieto et al. (2000). In the exploratory work on Atlantic hurricane frequency by García Herreraet al. (1999, 2001, 2002) hundreds of documents contained in the AGI, AHN, and AGS have been searched. Even when relevant documents are identified, great effort is often required to make them useful for climatological research. Thus, under the CLIWOC program, the development of the database involves reading more than 600 original logbooks, each of them containing hundreds of handwritten pages, transcribing the information into digital form, translation of the entries, and final editing to make a friendly database for the end user.

When one examines the examples mentioned throughout this paper from the methodological viewpoint, it can be seen that each type of project requires its own approach, often developed "ad hoc." Thus, for the Manila galleons a model had to be derived to describe the relationship between wind force and ship speed, virtual voyages had to be designed, and modern analogs constructed. For CLIWOC, it is necessary to develop "dictionaries" of meteorological terms to make the historical information, originally in four different languages, useful and comparable with modern data. The characterization of climate variability in Argentina required extensive application of content analysis. We have also seen that it is indispensable to combine the expertise of historians, climatologists, and meteorologists if it is desired to extract maximum information from historical documents. None of the studies described herein would have been possible had the research teams not combined such abilities.

To summarize, in order to design an effective research strategy, it seems necessary to have the following:

- information from diverse archival sources, both in Spain and in the Americas;

- a high level of archival expertise to extract the raw data, because the archives are usually organized according to administrative or historical considerations, and the use of geographical or climatological entries is not always sufficient;

- a preliminary historical-climatological analysis of the type of events and impacts for which data are searched (which will usually produce a more efficient search and is preferable to blind searches without any prior joint search criteria);

- a good grasp of the historical context to properly analyze the documents, assess their reliability, and obtain metadata that can be helpful in postprocessing; and

- expertise in the analysis of meteorological and climatological instrumental observations, which will usually help in extracting the full significance of noninstrumental data.

These complexities and difficulties should not discourage researchers interested in the field, because the process can yield very valuable results in the long run. The use of historical sources makes it possible to study climate phenomena over extensive geographical areas and on a broad range of timescales. And it must be borne in mind that, for many situations of climatic interest spanning several centuries before the instrumental era, there are simply no sources of information other than those contained in historical archives.

\section{REFERENCES}

Academia Nacional de la Historia, 1941-1946: Actas Capitulares de Corrientes. 4 Vols., Kraft, 1650 pp. —_ 1941-1951: Actas Capitulares de Santiago del Estero. 6 Vols., Kraft, 2340 pp.

Baron, W., 1982: The reconstruction of eighteenth century temperature records through the use of content analysis. Climate Change, 4, 385-398.

Fu, C., and J. Fletcher, 1988: Large signals of climatic variation over the ocean in the Asian monsoon region. Adv. Atmos. Sci., 5, 389-404.

García, R. R., and Coauthors, 2001: Atmospheric circulation changes in the tropical Pacific inferred from the voyages of the Manila galleons in the sixteenth- 
eighteenth centuries. Bull. Amer. Meteor. Soc., 82, 2435-2456.

García Herrera, R., M. R. Prieto, L. Gimeno, E. Hernández, E. López, and R. Herrera, 1999: The Archivo General de Indias as a source of climatic marine surface information. Proc. Int. Workshop on Digitization and Preparation of Historical Surface Marine Data and Metadata, Toledo, Spain, World Meteorological Organization, WMO/TD 957, 6168.

-, and Coauthors, 2001: El Galeón de Manila y el clima del Pacífico durante el siglo XVII. Estudios de Historia y Ambiente en América, B. García Martínez and M. del Rosario Prieto, Eds., El Colegio de México/IPGH, in press.

—, F. Rubio, D. Wheeler, E. Hernández, M. R. Prieto, and L. Gimeno, 2002: The use of Spanish and British documentary sources in the investigation of Atlantic hurricane incidence in historical times. Hurricanes: Past, Present and Future, R. Murnane and K. Liu, Eds., Columbia University Press, in press.

Gioda, A., and M. R. Prieto, 1999: Histoire des sécheresses andines. Potosí, El Niño et le Petit Age Glaciaire. La Météorologie, 8 (27), 33-42.

Jones, P. D., T. Jonsson, and D. Wheeler, 1997: Extension of the North Atlantic Oscillation using early instrumental pressure observations from Gibraltar and south-west Iceland. Int. J. Climatol., 17, 1433-1450.

Kalnay, E., and Coauthors, 1996: The NCEP/NCAR 40Year Reanalysis Project. Bull. Amer. Meteor. Soc., 77, 437-471.
Kistler, R., and Coauthors, 2001: The NCEP-NCAR 50-year reanalysis: Monthly means CD-ROM and documentation. Bull. Amer. Meteor. Soc., 82, 247268.

Luterbacher, J., C. Schmutz, D. Gyalistras, E. Xoplaki, and H. Wanner, 1999: Reconstruction of monthly $\mathrm{NAO}$ and EU indices back to AD 1675. Geophys. Res. Lett., 26, 2745-2748.

Morales Padrón, F., 1973: Historia del Descubrimiento y Conquista de América. Editora Nacional, 717 pp.

Ortlieb, L., 2000: The documented historical record of El Niño events in Perú: An update of the Quinn record (Sixteen through Nineteen Centuries). El Niño and the Southern Oscillation, H. F. Díaz and V. Markgraf, Eds., Cambridge University Press, 496 pp.

Prieto, M. R., R. Herrera, and P. Dussel, 2000: Archival evidence for some aspects of historical climate variability in Argentina and Bolivia during the 17th and 18th centuries. Southern Hemisphere Paleo and Neoclimates, W. Volkheimer and P. Smolka, Eds., Springer-Verlag, 57-69.

Quinn, W. H., and V. T. Neal, 1992: The historical record of El Niño events. Climate Since A.D. 1500, R. Bradley and P. Jones, Eds., Routledge, 623-648.

,-- , $\_$and S. E. Antúnez de Mayolo, 1987: El Niño occurrences over the past four and a half centuries. J. Geophys. Res., 92, 14 449-14 461.

Udías, A., 1996: Jesuits' contributions to meteorology. Bull. Amer. Meteor. Soc., 77, 2307-2316.

Wheeler, D. A., 1988: Sailing ship logs as weather records: A test case. J. Meteor., 13, 122-126. 